\title{
Sustained impact of holistic specimens for mammalogy and parasitology in South America: Sydney Anderson's legacy
}

\author{
Jonathan Dunnum ${ }^{1 *}$, Jason Malaney $^{1,2}{ }^{2}$, And Joseph CoOK $^{1}$ \\ ${ }^{1}$ Museum of Southwestern Biology, University of New Mexico. MSC02-3030 87131, Albuquerque, New Mexico, USA. Email: \\ jldunnum@unm.edu (JLD), tucojoe@gmail.com (JAC). \\ ${ }^{2}$ New Mexico Museum of Natural History and Science, 1801 Mountain Rd, NW, 87104, Albuquerque, New Mexico, USA. Email: \\ jmalaney@gmail.com (JM). \\ ${ }^{*}$ Corresponding author
}

\begin{abstract}
Sydney Anderson and the "Mammalian Diversity in Bolivia" (MDB) project (1984-1993) established a highly productive model for integrated specimen-based field expeditions. We assess the extended impact of that decade-long series of holistic surveys of mammalian diversity as a productive model for building enduring and highly integrated infrastructure for biodiversity research. We point to specific examples of impact, but more generally make a case for Sydney Anderson's prescient view that collections, over time, become ever more powerful and essential scientific tools for understanding mammalian diversity and our rapidly changing planet. To assess the number of specimens held in collections and their availability for spatial analyses, we queried the Global Biodiversity Information Facility (GBIF) for Bolivian specimens. Results were downloaded and non-georeferenced specimens were georeferenced in GeoLocate. Publications utilizing specimens or data from the MDB project were identified in Google Scholar, these were used to build a citation profile to analyze impact and breadth of research. Over the course of the decade-long MDB project ca. 10,000 new "holistic" specimens were added to natural history collections in Bolivia and the United States. These specimens and data were used in over 500 papers across a broad range of research areas, including new records for the country, and many descriptions of mammals (nine) and parasites (34) new to science. The Google Scholar profile generated for these publications has more than 20,000 citations and a citation H-index $=68$ and an i-10 $=340$. Sydney Anderson's legacy will endure through the exceptional collections he helped to build and the wide array of students he helped to inspire. As societal concerns related to environmental change (e. g., biological annihilation, climate change, emerging zoonotic pathogens) become more pressing, scientific questions evolve, and technology continues to develop, these critical resources will be called upon more and more frequently. Thus we can confidently predict that the value and use of the Bolivian mammal specimens archived under Syd Anderson's leadership will continue to increase in the future.
\end{abstract}

Sydney Anderson y el proyecto "Diversidad de mamíferos en Bolivia" (MDB; 1984-1993) establecieron un modelo altamente productivo para expediciones integrales de campo basadas en muestras. Evaluamos el impacto extendido de esa serie de estudios holísticos de la década de la diversidad de mamíferos como modelo productivo para construir una infraestructura duradera y altamente integrada para la investigación de la biodiversidad. Se señalan ejemplos específicos del impacto, pero en general exponemos la visión premonitoria de Sydney Anderson respecto a que las colecciones, con el tiempo, se convertirán en herramientas científicas cada vez más poderosas y esenciales para comprender la diversidad de mamíferos y a nuestro planeta que cambia rápidamente. Para evaluar el número de especímenes almacenados en colecciones y su disponibilidad para análisis espaciales, consultamos el Global Biodiversity Information Facility (GBIF) para especímenes de Bolivia. Los resultados se descargaron y las muestras no georreferenciadas se georreferenciaron en GeoLocate. Las publicaciones con muestras o datos del proyecto MDB se identificaron en Google Scholar y se utilizaron para crear un perfil de citas, analizar el impacto y la amplitud de la investigación. En el transcurso de una década del proyecto de MDB se agregaron aproximadamente 10,000 nuevos especímenes "holísticos" a las colecciones de historia natural en Bolivia y los Estados Unidos. Estos especímenes y datos se utilizaron en más de 500 artículos referidos a una amplia gama de temas y áreas de investigación, incluyendo nuevos registros para el país y descripciones de mamíferos (9) y parásitos (34) nuevos para la ciencia. El perfil de Google Scholar generado para estas publicaciones tiene más de 20,000 citas y un índice de citación $\mathrm{H}=68$ y i-10 $=340$. El legado de Sydney Anderson perdurará en el tiempo a través de las excepcionales colecciones que ayudó a construir y la amplia gama de estudiantes que ayudó a inspirar. . A medida que las preocupaciones sociales relacionadas con el cambio ambiental (por ejemplo, la aniquilación biológica, el cambio climático, los patógenos zoonóticos emergentes) se vuelven más acuciantes, las preguntas científicas evolucionan y la tecnología continúa desarrollándose, estos recursos críticos se recurrirán cada vez con mayor frecuencia. Por lo tanto, podemos predecir con confianza que el valor y el uso de los especímenes de mamíferos bolivianos bajo el liderazgo de Syd Anderson continuarán aumentando en el futuro.

Keywords: biodiversity infrastructure; Bolivia; mammals; natural history collection.

C 2020 Asociación Mexicana de Mastozoología, www.mastozoologiamexicana.org

\section{Introduction}

"..... (I) have done what I could to encourage and expedite the work of others on these taxa, although it is frustrating, in a way, to leave so many of them unresolved."

(Sydney Anderson 1997, Mammals of Bolivia).
Despite his sentiment on leaving matters unresolved, there is little doubt that Sydney Anderson left a legacy that will not only endure, but grow, as the biodiversity infrastructure he helped build is used by generations of scientists to come. 
Over a decade of fieldwork (1984-1993), the Mammalian Diversity in Bolivia (MDB) survey established a highly productive model for integrated specimen-based field expeditions. With funding from the National Science Foundation and under the leadership of Sydney Anderson (American Museum of Natural History, AMNH), Terry Yates and Joseph Cook (Museum of Southwestern Biology, University of New Mexico, MSB), and Scott Gardner (University of CaliforniaDavis, UCD and the Manter Laboratory of Parasitology, University of Nebraska, Lincoln, HWWL), this highly collaborative project involved a number of Bolivian institutions including the Colección Boliviana de Fauna in the La Paz (CBF), the Museo de Historia Natural "Noel Kempff Mercado" in Santa Cruz, Bolivia (MHNNKM), Centro Nacional de Enfermedades Tropicales (CENETROP), Zoofauna SudAmericana-Santa Cruz, Instituto Boliviano de Biología de la Altura, La Paz (IBBA), and Instituto de Ecología, Universidad Mayor de San Andrés (UMSA). The MDB represented the initiation of a more rigorous, comprehensive, and integrated methodology in specimen preparation, designed to encompass not just the mammal and its morphologic characters, but to also archive as broad a spectrum of tissues as possible, and with a dual focus on each mammal specimen's associated parasites. The traditional voucher (skin and skeleton-- Hafner et al. 1984, or fluid preserved specimen) was supplemented by an array of ultrafrozen tissues, chromosome cell suspensions, fecal samples, and endo and ectoparasites. Now termed the "Holistic Specimen" (Cook et al. 2016; Galbreath et al. 2019), but also known as the "Extended Specimen" (Webster 2017), these specimens provide a breadth of materials to address not only traditional systematic and taxonomic questions, but now facilitate and integrate questions in environmental change (e. g., climate change, habitat conversion, pollutants and toxicants, biodiversity loss, introduction of exotics), and other novel and evolving contemporary research areas (e. g., pathogen emergence and discovery, genomics, microbiomes, isotopic and molecular ecology, metagenomics, transcriptomics, and proteomics; Cook et al. 2017; Dunnum et al. 2017; Greiman et al. 2018; Schindel and Cook 2018).

The MDB project produced more than 10,000 holistic mammal specimens from diverse biomes throughout "el Corazón de Sudamérica". These materials are now deposited in the collections of the AMNH, CBF, MHNNKM, and MSB, along with thousands of lots of associated ectoparasites (e. g., fleas, ticks, lice) and endoparasites (e. g., helminths) that were deposited in the HWML. To date, those specimens and their related data have served as the basis for hundreds of publications and graduate theses. Many of those studies, in turn, have been highly cited, revealing how holistic mammalian surveys, if properly archived, can continue to produce diverse, integrated, novel perspectives on mammalian biology in this hyper-diverse region long after the initial field research is completed.

Collections serve as primary infrastructure for environmental science. Research questions using specimens today are often quite different from the original goals of specimen collection (McLean et al. 2016). The kinds of studies using samples and data from specimens have exploded (Pauli et al. 2017; Schmitt et al. 2018), yet sample availability for nearly all natural populations and species remains too limited (Malaney and Cook 2018). Sydney Anderson realized that building collections, essentially libraries of biodiversity, was key to ensuring their primary role in biodiversity sciences. Biodiversity sciences leverage this primary infrastructure in diverse ways. Herein, we point to how the integrated, holistic datasets uniquely offered by the Bolivian specimens have already improved understanding of geographic variation ( $e$. g., morphological, genomic, ecological), interactions among organisms (e. g., host-parasite, host-microbiome, habitat), and the relationship between humans and wildlife health and will continue to do so well into the future. Multiple fields and scientific approaches can use this primary infrastructure and associated datasets to build and test hypotheses about natural and anthropogenically altered phenomena.

In addition to building scientific collections, the MDB survey combined with Sydney Anderson's engagement with Bolivian national, regional, and university-based museums provided exceptional cross-cultural opportunities for both Bolivian and North American students (the next generation of specimen-based scientists) to gain hands on experience in field mammalogy, parasitology, and museum curation.

Here, we assess the extended impact of that decade long series of holistic surveys of mammalian diversity as a productive model for building enduring and highly integrated infrastructure for biodiversity and human health. We point to specific examples of impact, but more generally make a case for Sydney Anderson's prescient view that collections, over time, become ever more powerful and essential scientific tools for understanding mammalian diversity and our rapidly changing planet.

\section{Materials and methods}

To assess the number of specimens held in collections and their availability for spatial analyses, we queried the Global Biodiversity Information Facility (GBIF) using the following parameters: Basis of record - "preserved specimen"; Country or area -"Bolivia"; Scientific name -"Mammalia". During the MDB survey, AMNH did not have frozen tissue storage facilities so all tissue samples and karyotypes were deposited at the MSB. Tissues from traditional voucher specimens (skin/ skeleton/fluid specimens) held at the AMNH were cataloged as tissue only specimens at MSB and linked to the corresponding vouchers cataloged at AMNH though the Arctos collection management database (arctosdb.org). In GBIF this results in duplicate records for the same individual so for these analyses we removed duplicates. For those GBIF records without coordinate information, we georeferenced those with unambiguous localities using GeoLocate (http:// www.museum.tulane.edu/geolocate/; Rios and Bart 2014).

To identify publications which utilized MDB specimens or data, we used Google Scholar searches based on a series of keywords (e. g., Bolivia, mammal, MSB, AMNH, CBF, 
MNKM) and our knowledge of the material collected and loaned. This publication list was then used to accomplish two objectives: 1) assess the breadth of research for which MDB specimens contributed to, and 2) build a Google Scholar profile with citation indices to assess total impact.

Evaluation of the research content area was accomplished by assigning each publication to one of seven broad categories: 1) Systematics, taxonomy, and phylogeography, 2) New records/species distributions, 3) Taxon accounts in larger reference works, 4) Species compilations or keys, 5) Conservation and biogeography, 6) Parasite and pathogen biology and discovery, and 7) other areas.

\section{Results and discussion}

Impact on Bolivian natural history specimen growth. The beginnings of Bolivian mammalogical collections dates back to the early 1800's and continued sporadically into the early 1960's. Accurately accounting for all Bolivian specimens archived remains daunting due to incomplete digitization in the broad array of collections holding material, and was not attempted for this report. We estimate that no more than 5,000 specimens resulted from these early efforts documenting the country for the period 1818 through 1962. Tarifa (2014) and Anderson (1997) provide detailed overviews of the important events, people and institutions involved in the early years of Bolivian mammalogy. The ensuing decade (1960's) saw major projects focused on disease investigations related to a Bolivian hemorrhagic fever outbreak in the Beni region. These surveys by the Middle American Research Unit (MARU) and U. S. Army Medical Research and Development Command (USAMRD) generated large collections (ca. 13,000 specimens) now archived at the USNM, FMNH, and AMNH. The AMNH/USAMRD project led by Richard Van Gelder was Sydney's first foray into documenting Bolivian fauna and represents his first contributions to Bolivian mammalogy. Subsequently, from 1979-1983, Sydney (accompanied by his wife Justine) made various journeys to Bolivia to collect mammals (ca. 1,200 specimens) throughout the country. These trips would serve as the foundation for later expeditions with the CBF, MHNNKM, MSB, and HWWL (Anderson 1997). Over the course of the decade-long MDB survey about 10,000 new "holistic" specimens were preserved and added to museum collections (Table 1) and by the time he began work on "Mammals of Bolivia", he had access to about 36,000 specimens.

GBIF searches (GBIF.org; 19 April 2020) resulted in 36,249 records from 41 collections (GBIF Occurrence Download https://doi.org/10.15468/dl.rppf79) but that total includes specimens shared between MSB/AMNH. After removing duplicate records, 32,590 digitized specimens were available for analyses. Based on information provided in Anderson (1997) and Dunnum et al. (2018), we recognize there are also specimen records not available through GBIF and thus not reflected in the total, including the holdings of the four Bolivian natural history collections. Dunnum et al. (2018)
Table 1. Summary of expeditions from the Mammalian Diversity of Bolivia (MDB) survey (1984-1993).

\begin{tabular}{llr}
\hline Year & \multicolumn{1}{c}{ Locations (Department) } & $\begin{array}{r}\text { Approx. } \\
\text { Specimens }\end{array}$ \\
\hline 1984 & Oruro, Cochabamba, Beni, Santa Cruz & 1,200 \\
1985 & Beni, Chuquisaca, La Paz, Santa Cruz & 1,500 \\
1986 & Beni, Chuquisaca, La Paz, Oruro, Pando, Potosi, Tarija & 1,300 \\
1987 & Santa Cruz & 250 \\
1988 & Santa Cruz & 700 \\
1990 & Chuquisaca, Santa Cruz & 1,000 \\
1991 & Cochabamba, Santa Cruz, Tarija & 1,770 \\
1992 & Beni, La Paz, Santa Cruz & 770 \\
1993 & Beni, Cochabamba, La Paz & 1,300 \\
\hline
\end{tabular}

reported a total of about 14,000 specimens from those collections: Museo de Historia Natural "Alcide d'Orbigny" (MHNC-M; 166 specimens), Colección de Fauna Centro de Biodiversidad y Genética (CCBG; 265 specimens), MHNNKM (5,200 specimens), and CBF (8,211 specimens). Thus, we estimate the total number of Bolivian specimens to approach 50,000 , based on the combined GBIF data, un-digitized specimens held in other collections that we are aware of, and growth in collections since publication of Dunnum et al. (2018). Therefore, we estimate that there are approximately 0.045 specimens per $\mathrm{km}^{2}$ collected in Bolivia $(50,000 / 1.099$ million $\left.\mathrm{km}^{2}\right)$. About a third of the specimen records $(12,015$ specimens) in GBIF are not georeferenced, including much of the early collections by the Smithsonian (USNM), British Museum (NHMUK), and AMNH.

We (JLM) were able to georeference an additional 8,265 of those specimens to bring the total number to 28,834 . Thus, we produced specimen heat maps (Figure 1) which included ca. $89 \%$ of the specimens in GBIF, however, when also considering the specimens not available in GBIF, these analyses represent only about $60 \%$ of the total Bolivian collections. This reduction in specimens for spatial analyses, reinforces the point that full value of specimens is only realized when they are properly georeferenced, digitized, and made available on-line. Thus, while patterns seen in these maps are largely accurate based on our knowledge of the primary areas of collection in Bolivia, inclusion of the material held in the Bolivian natural history collections would certainly refine the precision of the spatial distribution of specimen coverage.

From a temporal sampling perspective, there exist almost no areas where there is adequate sampling through time (Figures $1 \mathrm{a}$ to $1 \mathrm{~d}$ ), material and data absolutely vital to robustly assessing any type of environmental change. The forty-year period until 1963 (Figure 1a) illustrates the overall relatively low numbers of specimens, collected primarily from the central and eastern portions of the country, with nearly half the country devoid of any sampling. The period from 1963-1983 (Figure 1b) exemplifies the impact of disease related projects in northern and western lowlands as well as bat surveys in La Paz and Santa Cruz departments. However, the southern highlands were largely unsampled during those twenty 

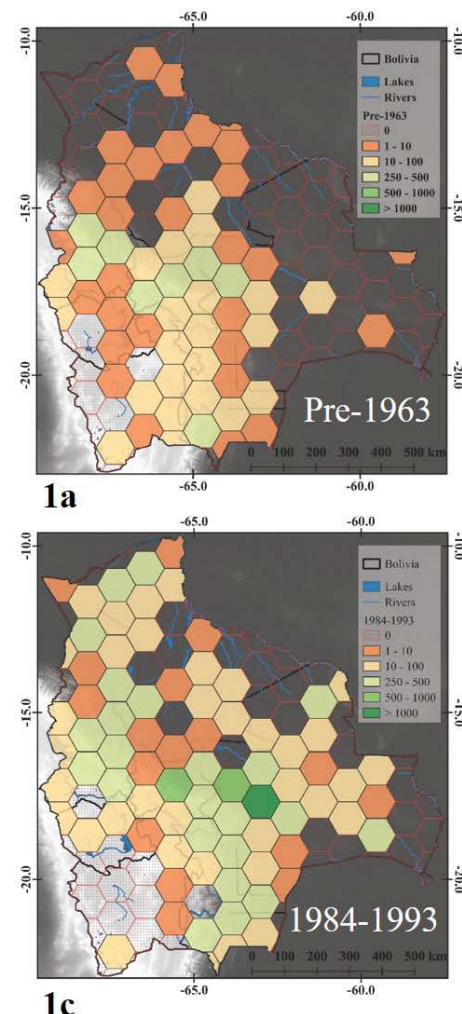
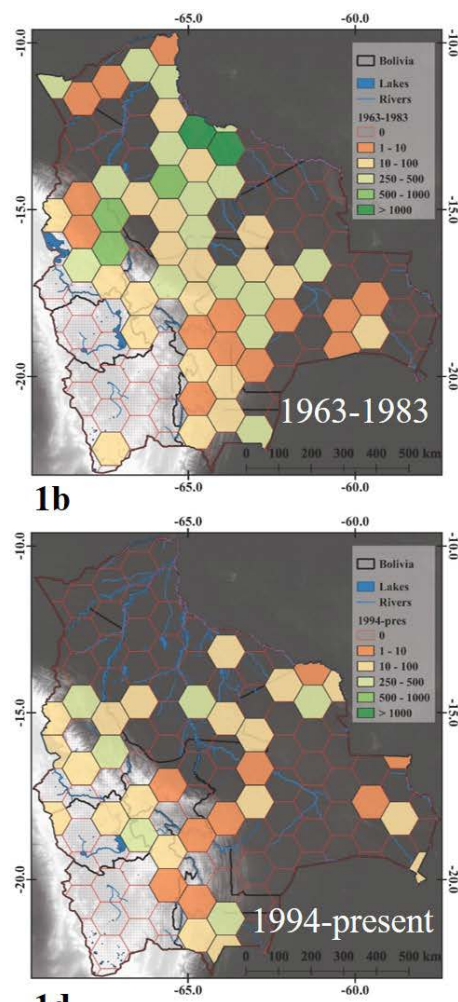

$1 d$

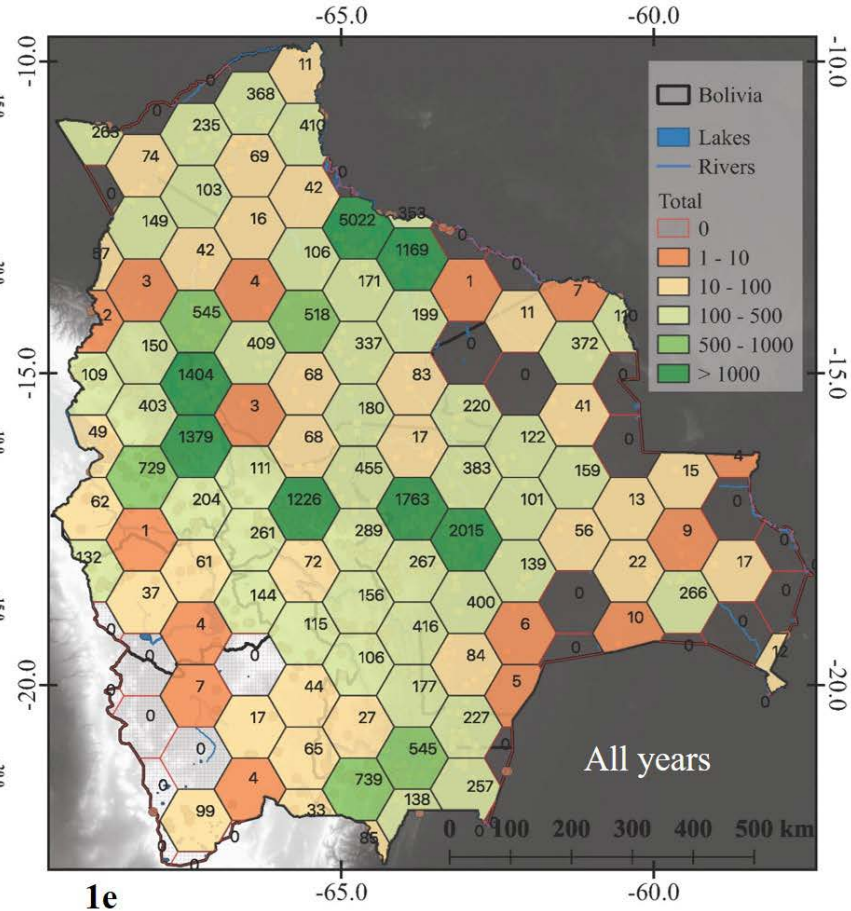

$1 \mathrm{e}$

Figure 1. Heat maps of Bolivian specimens available on GBIF and containing georeferenced data: 1a) specimens collected prior to 1963. 1b) specimens collected between 1963-1983.

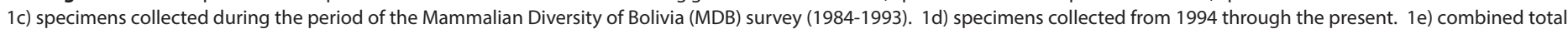
specimens for all years with numeric value for each hexagon noted.

years. The decade of the MDB surveys (Figure 1c) saw a major increase in sampling across the country but most prominently along the eastern versant of the Andes. Despite only representing a single decade, the MDB survey era represents the period of greatest spatial coverage. Despite gains made during that period, based on these data there has been a reduction in sampling over the past 20 years (Figure 1d), a period of significant global climate change and environmental alternations. These numbers perhaps would not look quite as grim if specimens from the Bolivian natural history collections were included because many of those represent recently collected material but the general issue would remain.

Pooling all specimens through time (Figure 1e) shows that about $60 \%$ of the country has $<100$ specimens/hex $\left(\sim 10,000 \mathrm{~km}^{2}\right)$, including areas in the southern highlands and the Bolivian Chaco which are extremely depauperate of material. About $90 \%$ of the areas within the country are represented by fewer than 500 specimens. The only areas with numbers over 1,000 are around the major urban centers of La Paz (2,783 specimens), Cochabamba (1,226 specimens), and Santa Cruz ( 3,778 specimens), and the BHF outbreak investigation area $(6,191$ specimens) in the Beni.

The take-home message remains that, like the majority of places on our planet, Bolivia remains vastly undersampled on both a spatial and temporal scale and there are many parts of the country which have already been irreparably altered through habitat conversion before they could be even partially documented. Large-scale funded projects like the MDB survey have the potential to make large con- tributions, but are unfortunately few and far between, thus broad spatial and temporal surveys of biodiversity need to be supported through diverse collaborations leveraging both in-country and global entities and resources.

Impact of Bolivian Specimen Infrastructure on Science. The MDB project developed new field-based protocols for preserving holistic specimens that would facilitate research that integrated across studies of hosts and parasites (Gardner 1996; Gardner and Jiménez-Ruiz 2009). These field techniques have been subsequently expanded and refined through other large sampling efforts worldwide with new cohorts of mammalogists and parasitologists (e. g., Beringian Coevolution Project, Cook et al. 2017). From those efforts, best practices in holistic sampling of mammal and parasite faunas (Galbreath et al. 2019) now codify the concept of the holistic mammal specimen. Having now advocated for the concept of the "holistic specimens", it must be said that Sydney Anderson was a proponent of saving any piece of animal material he encountered on the roadways of Bolivia, no matter how flattened or degraded as it might be. He would wryly note each "road-kill record" would add another "vouchered dot" on the distribution map for a particular species. More than a few specimens were composed of nothing more than a patch of skin scraped from the roadway, carefully annotated with location and date of collection. In retrospect, those materials were important as they often represented a larger, poorly sampled carnivore and are now irreplaceable because technology has advanced to the point of allowing the extraction of genetic or isotopic signatures from extremely marginal material. 
Sydney Anderson's years spent working in Bolivia and then reviewing the collections at MHNNKM, CBF, AMNH, or MSB produced many publications dealing with the distribution and systematics of this South American mammalian fauna (Anderson 1982, 1985, 1993, 1997; Anderson et al. 1982; Anderson and Olds 1989; Anderson et al. 1993; Anderson and Webster 1983; Anderson and Yates 2000; Anderson et al. 1987; Cook et al. 1990; Gardner and Anderson 2001; Glanz and Anderson 1990; Hinojosa et al. 1987; Olds and Anderson 1987, 1989; Olds et al. 1987; Salazar and Anderson 1990; Salazar et al. 1994). His monograph, "Mammals of Bolivia, Taxonomy and Distribution" (1997), has a place on every Neotropical mammalogist's bookshelf and has served as a vital resource for diverse research, public health, and wildlife management initiatives for three decades (670 citations). A growing body of subsequent works have built upon that foundational contribution.

Notwithstanding Sydney Anderson's published contributions to the systematics and taxonomy of Bolivia's mammalian fauna, his true Bolivian legacy may lie in the vast series of natural history specimens and associated data that he collected, compiled, organized, and curated over the decade he spent on this project. He was a seasoned and enthusiastic field mammalogist, even when setting his own traplines was no longer possible. He could always be counted on to finish preparing and check the work on all specimens. During the days, he would fastidiously monitor the progress on the drying skins and carcasses, often checking for maggots or mold, and moving the skeleton pile into direct sunlight or out of the rain. His catalog numbered in the 10,000 's, and he took it upon himself to not only prepare massive numbers of specimens while in the field but to also carefully document the activities of the day and the localities visited (Figure 2). Much of what he recorded would eventually make it into various accounts on Bolivian fauna, including his book "Mammals of Bolivia". The collections from the MDB survey also have fostered a wide array of research on mammals and associated parasites.

A series of Google Scholar searches identified over 500 papers that used specimens or associated data from the

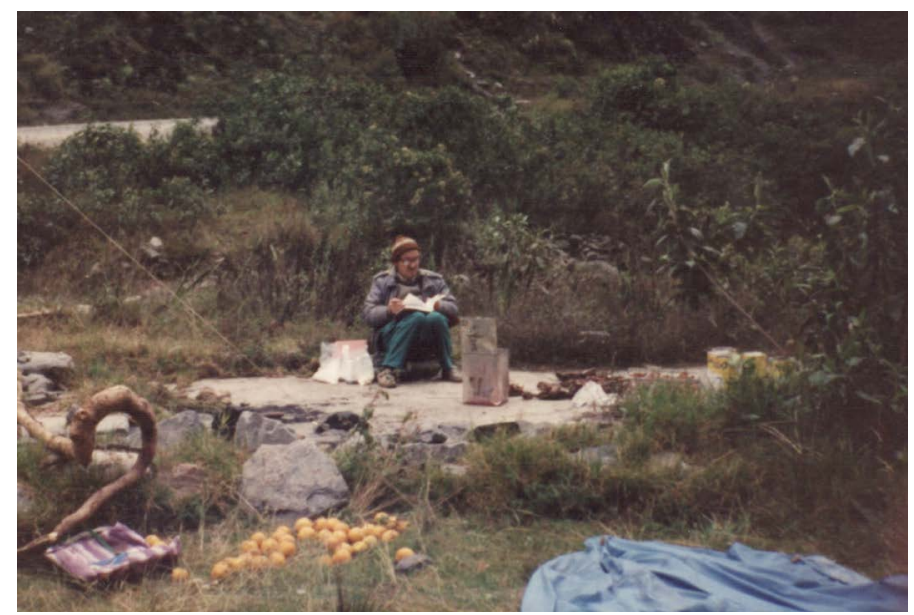

Figure 2. Syd Anderson writing fieldnotes and tending to drying specimens (Rio Aceromarca, La Paz Department, 1991).

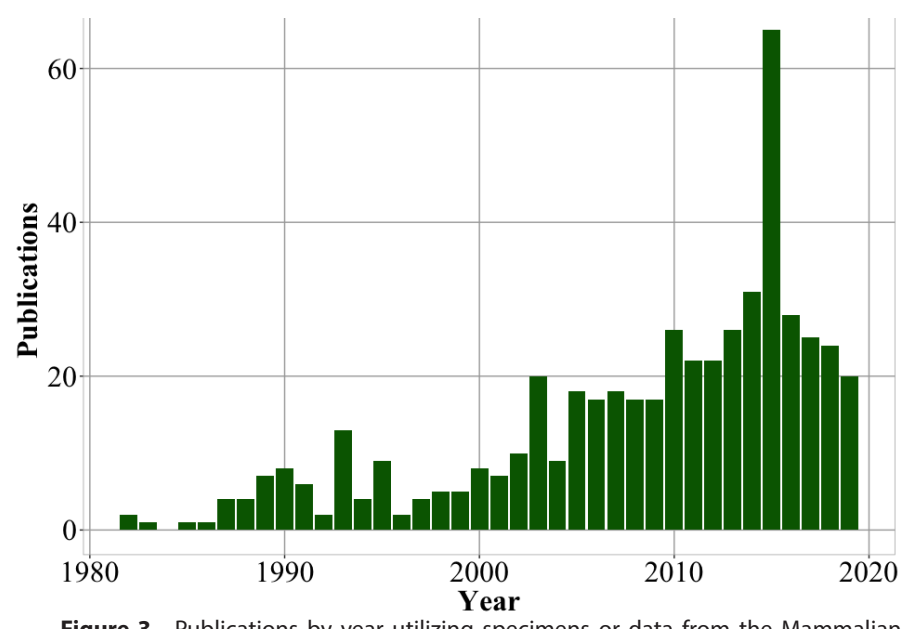

Figure 3. Publications by year utilizing specimens or data from the Mammalian Diversity of Bolivia survey.

MDB survey (Figure 3). It should be noted that only 49 of these papers were published during the life of the NSF grants, suggesting that the long-term value of specimenbased initiatives continue to generate value, as well as integrate knowledge across scientific fields, long after the grant cycle has concluded.

The suite of publications spanned most aspects of mammalian biology. As would be expected with specimenbased research, the majority of papers focused on mammalian systematics, taxonomy, or phylogeography. Specimens used in taxon accounts for larger reference works $(e$. g., Mammals of South America, Vol 2: Rodents (Patton et al. 2015) were the second largest area of use. New records, distributional extensions, and taxonomic lists and keys combined to made up about $10 \%$ of the papers. Conservation oriented papers constituted about $4 \%$ of the total, although many of the systematic, taxonomic and distributional papers also had a conservation emphasis. The utility of holistic specimens to bridge disciplines and contribute to integrated science is evidenced by the considerable number of papers which investigated mammalian parasite or pathogen biology (Figure 4). The integration and inclusion of both mammalogists and parasitologists on all MDB expeditions resulted in likely the largest collection of mammalian endoparasites from a Latin American fauna. To this day, these archived specimens continue to be a source of novel parasite discovery.

The Google Scholar profile generated for the > 500 publications of the MDB survey (https://scholar.google.com/cit ations? user $=860 \mathrm{kCvYAAAAJ \& hl=en \& authuser=2)}$ consists of over 20,000 citations (Figure $5 a$ ). The associated citation profile (total citations was 20,619, $\mathrm{H}$-index $=68$, i-10 index = 340; Figure $5 \mathrm{~b}$ ) undoubtedly has missed publications based on the MDB specimens, nonetheless, the profile demonstrates the enduring and increasing value of specimen-based holistic sampling of biodiversity (Cook et al. 2016; Schindel and Cook 2018), as recently summarized in the extended specimen concept (Lendemer et al. 2019). Far from being static specimens sitting idle in museum drawers or tissue samples slowly degrading in bioreposi- 
Conservation/Biogeography

(18), $4 \%$

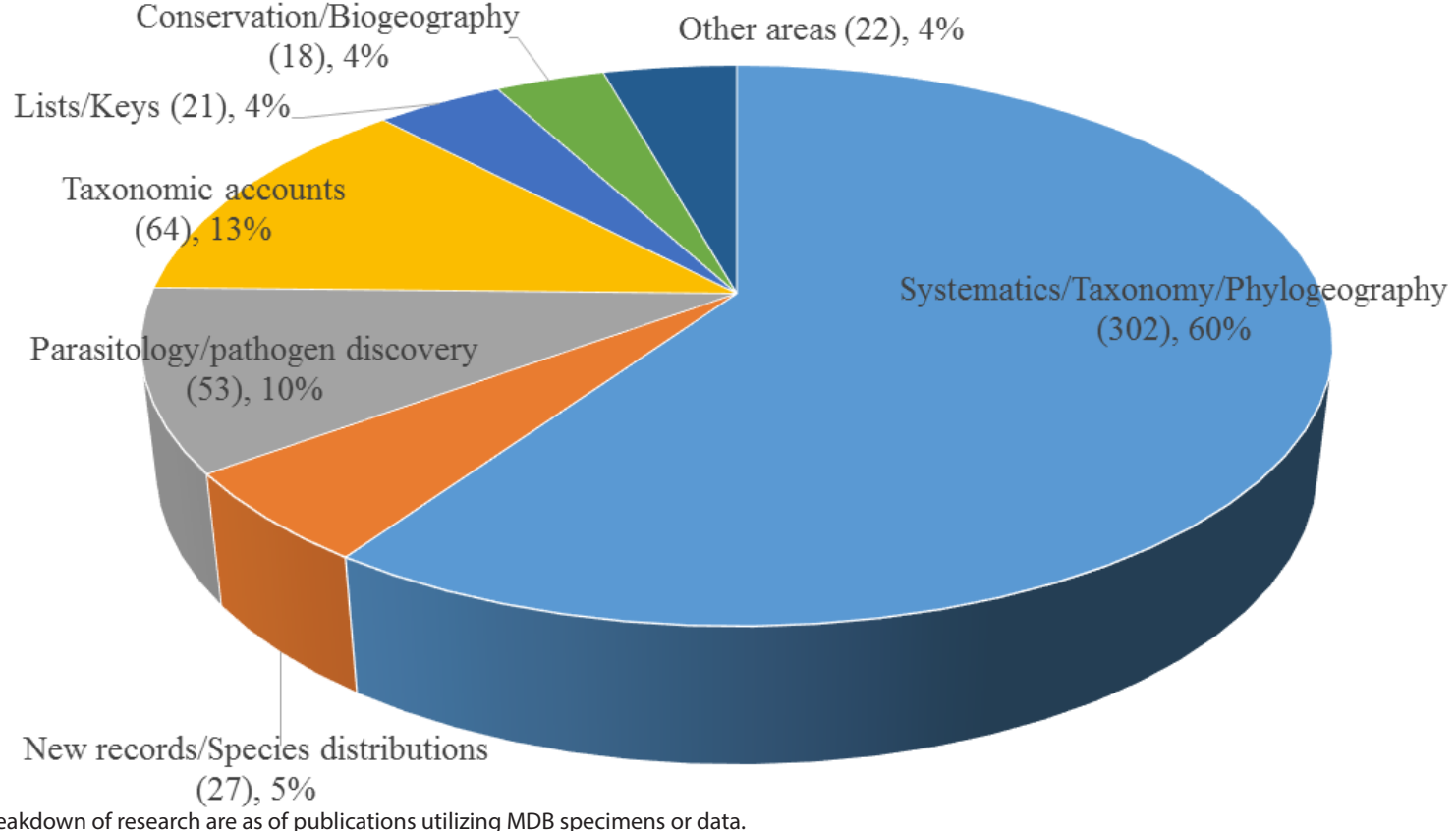

Figure 4. Breakdown of research are as of publications utilizing MDB specimens or data

tory freezers, these materials provide a vital foundation for ever more diverse sets of investigations because our ability to probe these materials has increased due to technological advances (e. g., genomics, viromics, stable isotope chemistry, 3-D ctScans, etc.) that are generating an everincreasing body of knowledge on South American mammals and their parasites. In addition, the steady increase in citations of these publications over the past three decades demonstrates both their centrality and enduring value as these irreplaceable materials are utilized for new questions and probed with new technologies (Figure $5 b$ ).

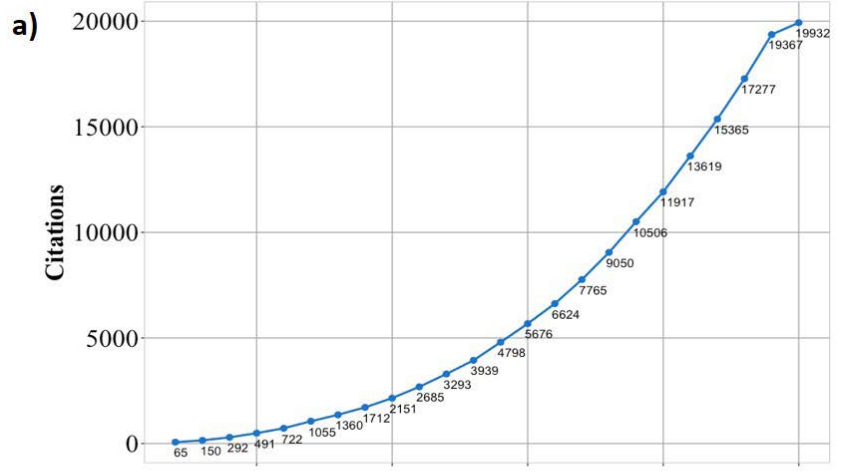

b)

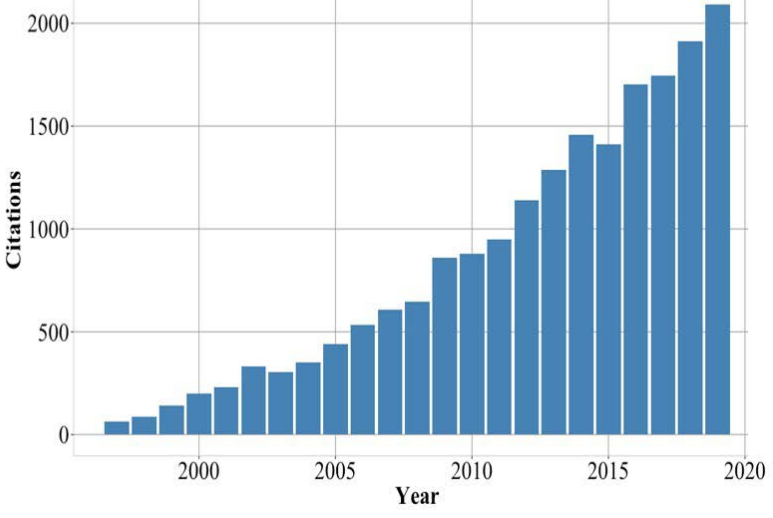

Figure 5. a) Cumulative growth curve of citations generated by MBD survey publications. b) Citations by year from the MDB survey.
A further demonstration of the power of specimens to integrate across diverse areas of investigation in biology and extend science is a MSB specimen of Andalgalomys pearsoni (MSB:Mamm:55245) collected from Santa Cruz department in 1984 by Sydney Anderson, Dwight Moore, and Joseph Cook in the first year of this project. That specimen was subsequently designated as the holotype of A. p. dorbignyi by Olds et al. (1987). The initial two genetic sequences were generated and accessioned in GenBank for inclusion in phylogenetic analyses accompanying the description of the new genus Tapecomys Anderson and Yates (2000) and a subsequent loan of material in 2002 to Scott Steppan's lab at Florida State University provided the other five sequences available in GenBank. These seven sequences have now been heavily utilized by other researchers.

Sequences in GenBank that are tied to permanent museum specimen are considered a best practice (Federhen et al. 2009) because these sequences can be verified and extended (from a single locus to full genomes) as technology improves our ability to probe samples. A significant percentage of GenBank data (up to 25\%) are incorrectly assigned to the wrong taxon (Longo et al. 2011) and cannot be re-examined as they are not tied to a permanent voucher. Direct links between GenBank and museum specimens have had major consequences for research in molecular genetics, genomics, and viromics by significantly expanding the accessibility of museum resources to a wider array of the scientific community. More than $50 \%$ of requests for tissue loans made to the Division of Genomic Resources at the Museum of Southwestern Biology now originate from investigators who have discovered this resource through GenBank. GenBank accessions in turn substantially solidify the role of specimens as primary infrastructure in biology. For example, data from specimens representing rare species are often used repeatedly as our knowledge of particular groups of organisms expands. A single specimen may 
voucher and integrate across many independent scientific studies. The impact of each specimen thus is amplified over time as the number of associated studies multiplies (Dunnum and Cook 2012). Thus since its deposition, this specimen of Andalgalomys pearsoni (MSB:Mamm:55245) has been part of the foundation of 32 publications (Figure 6).

Anderson (1985) reported 277 species for the country as of 1984. The most recent treatment of mammals of Bolivia includes 406 native species (Aguirre et al. 2019). This is an increase of 129 species since the initiation of the MDB survey. The large increase in the number of species registered for the country since 1984 (Figure 7) corresponds to a significant increase in specimen coverage, the breadth and quality of preserved material (including "holistic specimens" with ultra-frozen tissue), digital availability via the www, a cohort of young Latin American biologists, and new approaches in systematic research that provide more detailed views of geographic variation and species limits.
In addition to new distributional records from throughout the country, many descriptions of taxa new to science are based on the MDB collections, including nine mammals (Table 2) and at least 34 parasite taxa (Table 3).

Table 2. New descriptions of mammals from the Mammalian Diversity in Bolivia survey. Species Citation

\begin{tabular}{ll}
\hline Andalgalomys pearsoni dorbignyi & Olds, Anderson, and Yates, 1987 \\
Tapecomys primus & Anderson and Yates, 2000 \\
Thomasomys andersoni & Salazar-Bravo and Yates, 2007 \\
Ctenomys andersoni & Gardner, Salazar-Bravo, and Cook, 2014 \\
Ctenomys erikacuellarae & Gardner, Salazar-Bravo, and Cook, 2014 \\
Ctenomys lessai & Gardner, Salazar-Bravo, and Cook, 2014 \\
Ctenomys yatesi & Gardner, Salazar-Bravo, and Cook, 2014 \\
Akodon siberiae & Myers and Patton 1989 \\
Monodelphis sanctaerosae & Voss, Pine, and Solari 2012 \\
\hline
\end{tabular}

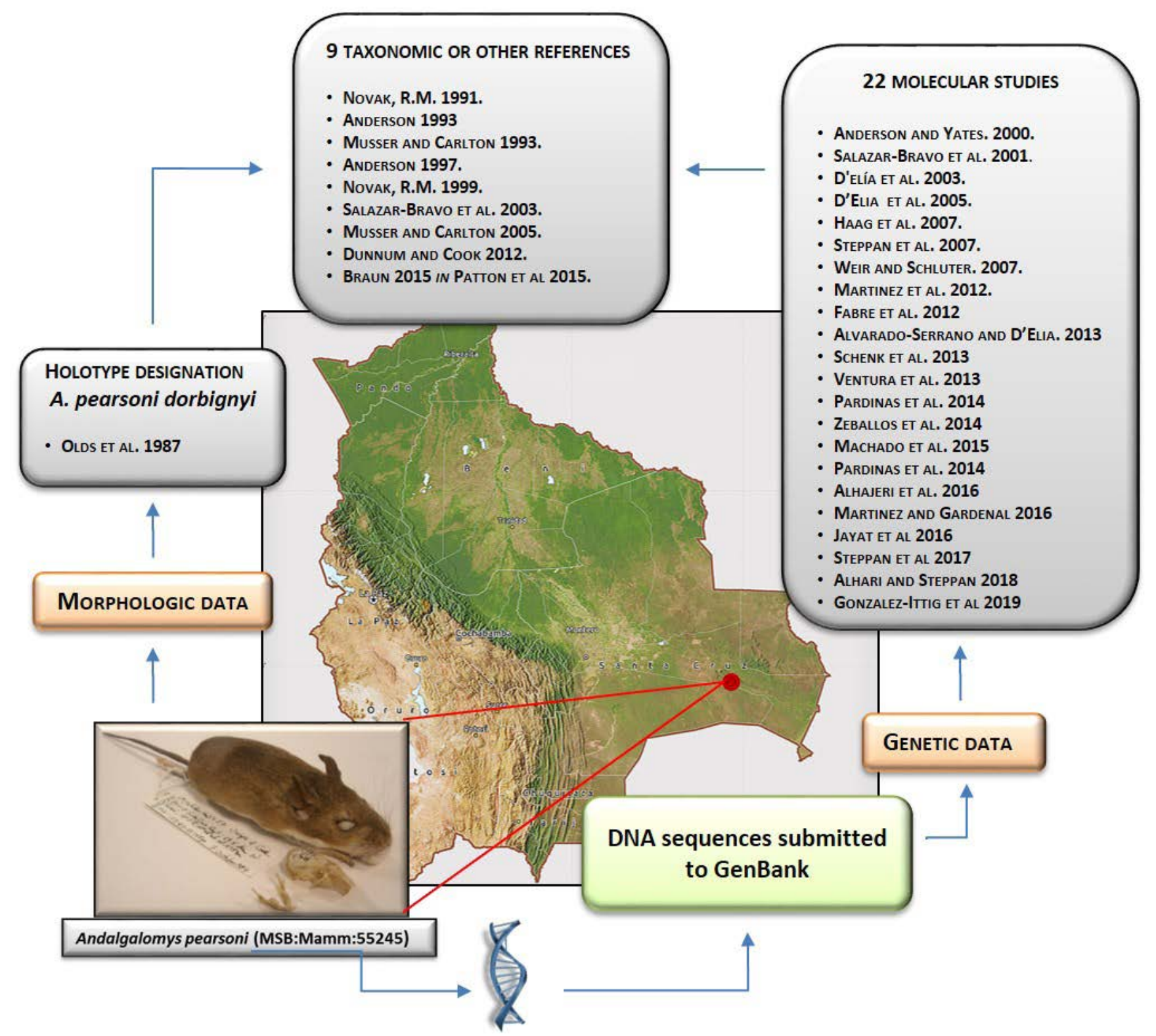

Figure 6. Citations for publications utilizing individual specimen of Andalgalomys pearsoni (MSB:Mamm:55245). 
Type material, including symbiotype specimens (Frey et al. 1992) for these new taxa are held at the MSB and AMNH. In addition to the biodiversity infrastructure developed by the MDB survey, it also had a profound effect on the individuals who took part in it. The inclusion of Bolivian and American students in all aspects of the MDB surveys provided experience, inspiration, and opportunities which would have life-long implications in their scientific development.

Many of these students credit their career choices and subsequent success to experiences gained and relationships made during these expeditions. Over the course of these projects at least 75 students ( 13 grad students, $>50$
Bolivian and 11 U.S. undergraduates) participated in field studies (Figures 8a, b) ranging from the Chaco of Tarija north to the Amazonian forests of the Pando, and from > $5000 \mathrm{~m}$ in the western Cordillera above the Altiplano eastward to $<500 \mathrm{~m}$ in the Chiquitano forests of eastern Santa Cruz. At least 29 of the students later received advanced degrees and many have now built successful careers in academia, natural history museums, or with conservation nongovernmental organizations (NGOs). The MDB survey, as well as concurrent and later USNM projects led by Louise Emmons, helped facilitate a surge in mammalogy in Bolivia and leading to a cohort of Bolivian biologists who took the torch and have now contributed massively to the understanding of the country's fauna.

Table 3. New descriptions of endo and ectoparasites from the Mammalian Diversity in Bolivia survey.

\begin{tabular}{|c|c|c|}
\hline Parasite & Host Species & Citation \\
\hline Andrya boliviensis & Phyllotis osilae & Havercost and Gardner 2010a \\
\hline Andrya vesicula & Phyllotis xanthopygus & Havercost and Gardner 2010a \\
\hline Caroloxyuris boliviensis & Oxymycterus paramensis & Jimenez-Ruiz and Gardner 2003a \\
\hline Cryptocotyle thapari & Lutra longicaudis & Gardner and Thew 2006 \\
\hline Didelphoxyuris thylamisis & Thylamys venustus & Gardner and Hugot 1995 \\
\hline Dipetalonema yatesi & Ateles chamek & Notarnicola et al. 2007 \\
\hline Eimeria boliviensis & Hydrochoerus hydrochaeris & Casas et al. 1995 \\
\hline Eimeria cochabambensis & Marmosops noctivagus & Heckscher et al. 1999 \\
\hline Eimeria granifera & Ctenomys opimus & Lambert et al. 1988 \\
\hline Eimeria ichiloensis & Hydrochoerus hydrochaeris & Casas et al. 1995 \\
\hline Eimeria magnirostrumi & Uroderma magnirostrum & Duszynski et al. 1999 \\
\hline Eimeria marmosopos & Marmosops ocellatus & Heckscher et al. 1999 \\
\hline Eimeria micouri & Micoureus constantiae & Heckscher et al. 1999 \\
\hline Eimeria montuosi & Ctenomys opimus & Lambert et al. 1988 \\
\hline Eimeria opimi & Ctenomys opimus & Lambert et al. 1988 \\
\hline Eimeria oruroensis & Ctenomys opimus & Lambert et al. 1988 \\
\hline Eimeria trinidadensis & Hydrochoerus hydrochaeris & Casas et al. 1995 \\
\hline Helminthoxys abrocomae & Abrocoma cinerea & Hugot and Gardner 2000 \\
\hline Laelaps neacomydis & Neacomys spinosus & Gettinger and Gardner 2005 \\
\hline Lauroia bolivari & Dasypus novemcinctus & Jimenez-Ruiz and Gardner 2003b \\
\hline Lentiella lamothei & Proechimys simonsi & Haverkost and Gardner 2008 \\
\hline Linstowia schmidti & Thylamys venustus & Gardner and Campbell 1992 \\
\hline Litomosoides andersoni & Ctenomys opimus & Brant and Gardner 1997 \\
\hline Litomosoides ctenomyo & Ctenomys opimus & Brant and Gardner 1997 \\
\hline Molinema boliviensis & Holochilus brasiliensis & Notarnicola et al. 2012 \\
\hline Monoecocestus andersoni & Graomys domorum & Haverkost and Gardner 2010b \\
\hline Monoecocestus eljefe & Galea leucoblephara & Haverkost and Gardner 2010b \\
\hline Monoecocestus microcephalus & Graomys domorum & Haverkost and Gardner 2010b \\
\hline Monoecocestus petiso & Galea musteloides & Haverkost and Gardner 2010b \\
\hline Monoecocestus poralus & Phyllotis caprinus & Haverkost and Gardner 2010b \\
\hline Monoecocestus sininterus & Tapecomys wolffsohni & Haverkost and Gardner 2010b \\
\hline Monoecocestus threlkeldi (redescription) & Holochilus brasiliensis & Haverkost and Gardner 2009 \\
\hline Pritchardia boliviensis & Marmosops noctivagus, Marmosops ocellatus, Metachirus nudicaudatus & Gardner et al. 2013 \\
\hline Yungasicola travassosi & Akodon mimus & Gardner and Perez-Ponce de Leon 2002 \\
\hline
\end{tabular}




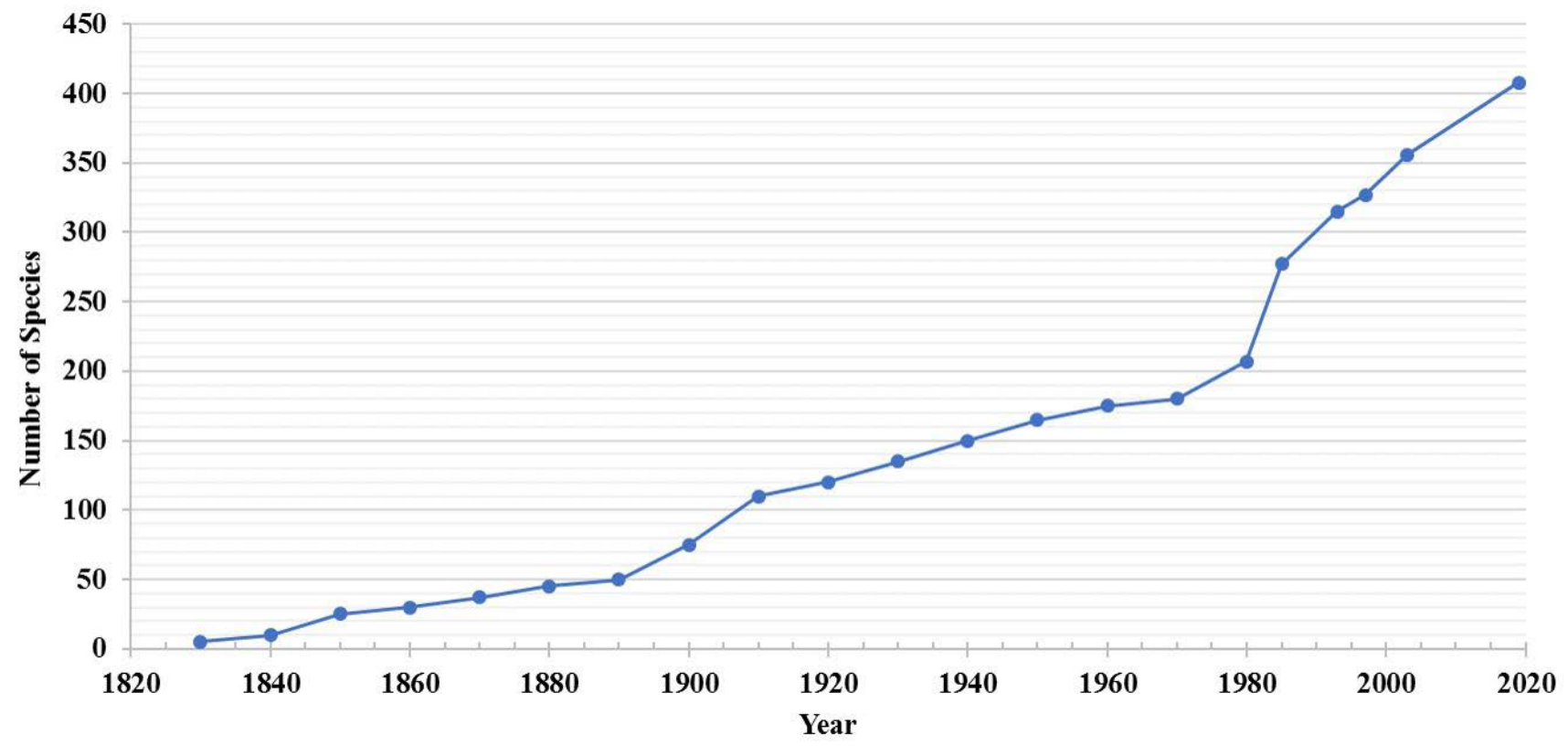

Figure 7. Accumulation of new species recorded for the country of Bolivia (modified from figure 1 in Aguirre, Tarifa et al. 2019).

Sydney Anderson was accorded the title of "El Padre de la Mastozoología Boliviana Contemporánea" (Tarifa 2014) for his four decades of research on Bolivian mammals and collection infrastructure. Four Bolivian mammals (Oryzomys andersoni Brooks et al. 2004; Thomasomys andersoni SalazarBravo and Yates 2007; Oecomys sydandersoni Carleton et al. 2009; Ctenomys andersoni Gardner et al. 2014) and one parasite (Litomosoides andersoni Brant and Gardner 1997) have now been named after Sydney Anderson. His name will certainly always be tied to the mammals of Bolivia but also to the generations of mammalogists he helped inspire and mentor along the way.

Critically, museums now not only provide materials for biodiversity studies, but they also serve a primary informatics role providing the associated original collection data (i. e., locality, date, taxonomic identity, measurements) through on-line databases (e. g., Arctos), and also serve as the nexus for connecting the ever-growing sets of bigdata (e. g., accessions to GenBank, IsoBank, MorphoBank, etc.) that were derived from these carefully preserved materials (Hedrick et al. 2020). We can confidently predict that the value and use of the Bolivian mammal specimens that were archived in multiple institutions in Bolivia and the United States under Sydney Anderson's leadership will continue to increase in the future as societal concerns related to environmental change (e. g., biological annihilation, climate change, emerging zoonotic pathogens) become more pressing, scientific questions evolve, and technology continues to develop. To this point, the current COVID-19 pandemic has highlighted our general unpreparedness to respond to emerging pathogens, fundamental ignorance of our planet's natural ecosystems, and the effects of our encroachment on them. Holistic collections are ideally positioned to play a fundamental role in a proactive response to future emerging disease scenarios (Cook et al. $\underline{2020}$ ), a role they can only play if grown in a manner championed by Sydney Anderson and colleagues.
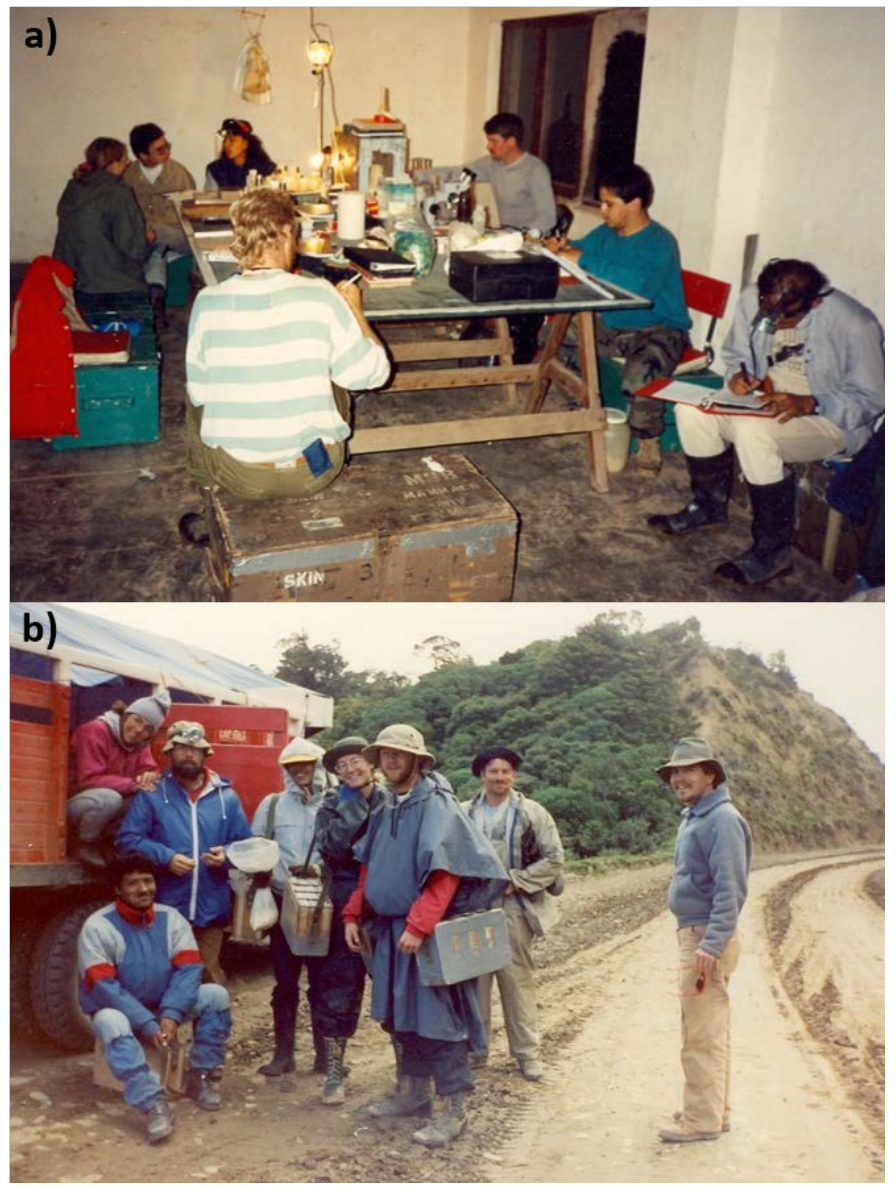

Figure 9. a) Mammalian Diversity in Bolivia survey students processing holistic voucher specimens (1991). From left; Mariel Campbell, Leonardo Maffei Fagale, Erika Cuellar Soto, Jon Dunnum, Forrest Davis, Jorge Salazar-Bravo, Marcello Zalles. b) Part of MDB field crew. From left: Nella Sanchez Cook, Jose Carlos Herrera, Jim Woods, Marcello Zalles, Mariel Campbell, Jon Dunnum, Forest Davis, Joe Cook) in Serrania Siberia in 1991. 


\section{Acknowledgements}

The experiences on the MDB survey were life changing and foundational to the development of our careers. Many of the relationships we made during those momentous field expeditions remain strong today and we often fondly recount our shared memories of adventures in the field with Syd. Special thanks to Jorge Salazar-Bravo, Scott Gardner and the many Bolivian and United States students who participated in the fieldwork during this decade and for their friendship, essential contributions, and in many cases, continued investment in the growth of Bolivian mammalogy and parasitology. The MDB survey collecting efforts were supported through funding from the National Science Foundation (BSR-83-16740, BSR-84-08923 Mammalian Diversity in Bolivia, BSR-86-12329, BSR-89-20617, BSR-90-15454 Mammalian Diversity in Bolivia: The Yungas and Valles (Renewal), BSR-90-24816 Parasites of Mammals of Bolivia: Phylogeny and Coevolution, INT-92-12839, and other funding agencies including the American Society of Mammalogists, Sigma Xi, The Hayward Fund at UNM, The Tinker Foundation, The Mellon Foundation (via the Latin American Institute of the University of New Mexico), The Embajada del Pais Baja in La Paz (Dutch Embassy), and Biological Society of New Mexico.

\section{Literature Cited}

Aguirre, L. F., T. Tarifa, R. B. Wallace, N. Bernal, L. Siles, E. Aliaga-Rossel, and J. Salazar-Bravo. 2019. Lista actualizada y comentada de los mamíferos de Bolivia. Ecología en Bolivia 54:107-147.

Anderson, S. 1982. Monodelphis kunsi. Mammalian Species 190:1-3.

Anderson, S. 1985. Lista preliminar de mamiferos bolivianos. Cuadernos de la Academia Nacional de Ciencias de Bolivia 65:5-16.

Anderson, S. 1993. Los mamiferos bolivianos: notas de distribucion y claves de identificacion. Publicación Especial del Instituto de Ecología (Colección Boliviana de Fauna), La Paz.

Anderson, S. 1997. Mammals of Bolivia, taxonomy and distribution. Bulletin of the American Museum of Natural History 231:1-652.

Anderson, S., K. F. Koopman, And G. K.Creighton. 1982. Bats of Bolivia: an annotated checklist. American Museum Novitates 2750: 1-24.

Anderson, S., ANd N. Olds. 1989. Notes on Bolivian mammals. 5, Taxonomy and distribution of Bolomys (Muridae, Rodentia). American Museum Novitates 2935:1-22.

Anderson, S., B. Riddle, T. Yates, And J. A. Cook. 1993. Mamiferos en la region del Parque Nacional de Amboro y Santa Cruz de la Sierra, Bolivia. Special Publication, The Museum of Southwestern Biology 2:1-58.

Anderson, S., And W. D. Webster. 1983. Notes on Bolivian mammals. 1, Additional records of bats. American Museum Novitates 2766:1-3.

Anderson, S., And T. L. Yates. 2000. A New Genus and Species of Phyllotine Rodent from Bolivia. Journal of Mammalogy 81:18-36.
Anderson, S., T. L. Yates, And J. A. Cook. 1987. Notes on Bolivian mammals 4: The genus Ctenomys (Rodentia: Ctenomyidae) in the lowlands. American Museum of Natural History Novitates 2891:1-19.

Brant, S. V., and S. L Gardner. 1997. Two New Species of Litomosoides (Nemata: Onchocercidae) from Ctenomys opimus (Rodentia: Ctenomyidae) on the Altiplano of Bolivia. The Journal of Parasitology 83:700-705.

Brooks, D. M., R. J. Vargas M., T. Tarifa, H. Aranibar, and J. M. Rojas. 2004. A new species of Oryzomys (Rodentia: Muridae) from an isolated pocket of Cerrado in Eastern Bolivia. Occasional Papers of the Museum of Texas Tech University 241:1-11.

Carleton, M. D., L. H. Emmons, and G. G. Musser. 2009. A new species of the rodent genus Oecomys (Cricetidae: Sigmodontinae: Oryzomyini) from eastern Bolivia, with emended definitions of $O$. concolor (Wagner) and O. mamorae (Thomas). American Museum Novitates 3661:1-32.

Casas, M. C., D. W. Duszynski, AND L. M. Zalles. 1995. Three new eimerians in capybara (Hydrochaeris hydrochaeris) populations from eastern Bolivia and southern Venezuela. The Journal of Parasitology 81:247-251.

Cook, J. A. 2018. Primary infrastructure for mammalogy in the Anthropocene. Mastozoologia Neotropical 25:267-268.

Cook, J. A., S. Anderson, AND T. L. Yates. 1990. Notes on Bolivian mammals 6: The genus Ctenomys (Rodentia: Ctenomyidae) in the highlands. American Museum of Natural History Novitates 2980:1-27.

Cook, J. A., S. Arai, B. Armién, J. Bates, C. A. Carrion Bonilla, M. B. de Souza Cortez, J. L. Dunnum, A. W. Ferguson, K. M. Johnson, F. A. Anwarali Khan, D. L. Paul, D. M. Reeder, M. A. Revelez, N. B. Simmons, B. M. Thiers, C. W. Thompson, N. S. Upham, M. P. M. Vanhove, P. W. Webala, M. Weksler, R. Yanagihara, and P. S. Soltis. 2020. Integrating Biodiversity Infrastructure into Pathogen Discovery and Mitigation of Emerging Infectious Diseases. BioScience DOI:10.1093/biosci/biaa064.

Cook, J.A., K. E. Galbreath, K. C. Bell, M. L. Campbell, S. Carrière, J. P. Colella, N. G. Dawson, J. L. Dunnum, R. P. Eckerlin, S. E. Greiman, V. Fedorov, G. M. S. Hass, V. Haukisalmi, H. Henttonen, A. G. Hope, D. Jackson, T. Jung, A. V. Koehler, M. Kinsella, D. Krejsa, S. J. Kutz, S. Liphardt, S. O. MacDonald, J. L. Malaney, A. Makarikov, J. Martin, B, S. Mclean., R. Mulders, B. Nyamsuren, S. L. Talbot, V. V. Tkach, A. Tsvetkova, H. M. Toman, E. C. Waltari, J. L. Whitman, and E. P. Hoberg. 2017. The Beringian Coevolution Project: Holistic Collections of Mammals and Associated Parasites Reveal Novel Perspectives on Evolutionary and Environmental Change in the North. Arctic Science 3:585-617.

Cook, J. A., S. Greiman, S. Agosta, R. P. Anderson, B. S. Arbogast, R. J. Baker, W. Boeger, R. D. Bradley, D. R. Brooks, R. Cole, J. R. Demboski, A. P. Dobson, J. L. Dunnum, R. P. Eckerlin, J. Esselstyn, K. Galbreath, J. Hawdon, H. Hoekstra, S. Kutz, J. Light, L. Olson, B. D. Patterson, J. L. Patton, A. J. Phillips, E. Rickart, D. S. Rogers, M. Siddall, V. TKach, and E. P. Hoberg. 2016. Transformational principles for NEON sampling of mammalian parasites and pathogens: a response to Springer and colleagues. BioScience 66:917-919.

Cook, J. A., AND J. E. Light. 2019. The emerging role of mammal collections in 21 st century mammalogy. Journal of Mammalogy 100:733-750. 
Dunnum, J. L., AND J. A. Cook. 2012. Gerrit Smith Miller: his influence on the enduring legacy of natural history collections. Mammalia 76:365-373.

Dunnum, J. L., B. S. McLean, and R. C. Dowler, and the Systematic Collections Committee of the American Society of Mammalogists. 2018. Mammal collections of the Western Hemisphere: a survey and directory of collections. Journal of Mammalogy 99:1307-1322.

Dunnum, J. L., R. Yanagihara, K. M. Johnson, B. Armien, N. Batsaikhan, L. Morgan, and J. A. Cook. 2017. Biospecimen repositories and integrated databases as critical infrastructure for pathogen discovery and pathobiology research. PLoS Neglected Tropical Diseases 11:p.e0005133.

Duszynski, D. W., D. T. Scott, And X. Zhao. 1999. Eimeria from Bats of Bolivia: Two New Species from Vespertilionid Bats. The Journal of Parasitology 85:504-507.

Federhen, S., C. Hotton, and I. Mizrachi. 2009. Comments on the paper by Pleijel et al. (2008): vouching for Gen-Bank. Molecular Phylogenetics and Evolution 53:357-358.

Frey, J. K., T. L. Yates, D. W. Duszynski, W. L. Gannon, and S. L. GARDNER. 1992. Designation and curatorial management of type host specimens (symbiotypes) for new parasite species. The Journal of Parasitology 78:930-932.

Galbreath, K. E., E. P. Hoberg, J. A. Cook, B. Armién, K. C. Bell, M. L. Campbell, J. L. Dunnum, A. T. Dursahinhan, R. P. Eckerlin, S. L. Gardner, and S. E. Greiman. 2019. Building an integrated infrastructure for exploring biodiversity: field collections and archives of mammals and parasites. Journal of Mammalogy 100:382-393.

Gardner, S. L. 1996. Essential techniques for collection of parasites during surveys of mammals. Pp. 291-298 in: Measuring and Monitoring Biological Diversity-Standard Methods for Mammals (D. Wilson, R. Cole, J. D. Nichols, R. Rudran, and M. Foster, eds.). Smithsonian Institution Press. Washington, D.C, U.S.A.

Gardner, S. L., And S. Anderson. 2001. Persistent Fontanelles in Rodent Skulls. American Museum Novitates 3327:1-15.

Gardner, S. L., And M. L. Campbell. 1992. A new species of Linstowia (Cestoda: Anoplocephalidae) from marsupials in Bolivia. The Journal of Parasitology 78:795-799.

Gardner, S. L., AND J. P. Hugot. 1995. A new pinworm, Didelphoxyuris thylamisis N. Gen. N. Sp. (Nematoda: Oxyurida) from Thylamys elegans (Waterhouse, 1839) (Marsupialia: Didelphidae) in Bolivia. Research and Reviews in Parasitology 55:139-147.

Gardner, S. L. And F. A. Jiménez-Ruiz. 2009. Methods of endoparasite analysis. Pp. 795-805 in Ecological and Behavioral Methods for the Study of Bats (Kunz, T., and S. Parsons, eds.). Johns Hopkins University Press. Baltimore, U.S.A.

Gardner, S.L., F. A. Jiménez Ruiz, and M. L. Campbell. 2013. Pritchardia boliviensis n. gen., n. sp. (Anoplocephalidae: Linstowinae), a tapeworm from opossums (Didelphidae) in the Yungas and lowlands of Bolivia and Atlantic Forest of Paraguay. Occasional Papers, Museum of Texas Tech University 319:1-8.

Gardner, S. L., And G. Pérez-Ponce de Léon. 2002. Yungasicola travassosigen.n.,sp.n.(Digenea:Dicrocoeliidae:Eurytrmatinae) from Two Species of Grass Mice of the Genus Akodon Meyen
(Rodentia: Muridae) from the Yungas of Bolivia. Comparative Parasitology 69:51-57.

Gardner, S. L., J. Salazar-Bravo, and J. A. Cook. 2014. New species of Ctenomys Blainville 1826 (Rodentia: Ctenomyidae) from the lowlands and central valleys of Bolivia. Special Publications, Museum of Texas Tech University 62:1-34.

Gardner, S. L., AND P.T.Thew. 2006. Redescription of Cryptocotyle thapari Mclntosh, 1953 (Trematoda: Heterophyidae), in the River Otter Lutra longicaudis from Bolivia. Comparative Parasitology 73:20-23.

Gettinger, D., And S. L. Gardner. 2005. Bolivian Ectoparasites: A new species of Laelapine Mite (Acari: Parasitiformes, Laelapidae) from the rodent Neacomys spinosus. The Journal of Parasitology 91:49-52.

Glanz, W. E., And S. Anderson. 1990. Notes on Bolivian mammals. 7, A new species of Abrocoma (Rodentia) and relationships of the Abrocomidae. American Museum Novitates 2991:1-32.

Greiman, S., J. A. Cook, V. V. Tkach, E. P Hoberg, D. Menning, A. G. Hope, S. A Sonsthagen, And S. L. Talbot. 2018. Museum metabarcoding: a novel method revealing gut helminth communities of small mammals across space and time. International Journal of Parasitology 48:1061-1070.

Hafner, D. J., J. C. Hafner, And M. S. Hafner. 1984. Skin-plus skeleton preparation as the standard mammalian museum specimen. Curator 27:141-145.

Haverkost, T. R., And S. L. Gardner. 2008. A new species of Lentiella (Cestoda: Anoplocephalidae) from Proechimys simonsi (Rodentia: Echimyidae) in Bolivia. Revista de Mexicana de Biodiversidad 79:99-106.

Haverkost, T. R., and S. L. Gardner. 2009. A redescription of three species of Monoecocestus (Cestoda: Anoplocephalidae) including Monoecocestus threlkeldi based on new material. Journal of Parasitology 95:695-701.

Haverkost, T. R., and S. L. Gardner. 2010a. Two new species of Andrya (Cestoda Anoplocephalidae) from Sigmodontine rodents in the Neotropics. Comparative Parasitology 77:145-153.

Haverkost, T. R., and S. L. Gardner. 2010b. New Species in the Genus Monoecocestus (Cestoda:Anoplocephalidae) from Neotropical Rodents (Caviidae and Sigmodontinae). Journal of Parasitology 96:580-595.

Heckscher, S. K., B. A. Wickesberg, D. W. Duszynski, and S. L. Gardner. 1999. Three new species of Eimeria from Bolivian marsupials. International Journal for Parasitology 29:275-284.

Hedrick, B. P., J. M. Heberling, E. Meineke, K. G. Turner, C. J. Grassa, J. Kennedy, J. Clarke, J.A. Cook, D.C. Blackburn, S. V. Edwards, AND C. C. Davis. 2020. Digitization and the future of natural history collections. BioScience 69:812-822.

Hinojosa, P., S. Anderson, J. L. and Patton. 1987. Two new species of Oxymycterus (Rodentia) from Peru and Bolivia. American Museum Novitates 2898:1-17.

Hugot, J. P., And S. L. Gardner. 2000. Helminthoxys abrocomae n. sp. (Nematoda: Oxyurida) from Abrocoma cinerea in Bolivia. Systematic Parasitology 47:223-230.

Jiménez-Ruiz, F. A., And S. L. Gardner. 2003a. The nematode fauna of long-nosed mice Oxymycterus spp. from the Bolivian Yungas. The Journal of Parasitology 89:299-308. 
Jiménez-Ruiz, F. A., AND S. L. Gardner. 2003b. Aspidoderid Nematodes from Bolivian Armadillos, with the Description of a New Species of Lauroia (Heterakoidea: Aspidoderidae). The Journal of Parasitology 89:978-983.

Lambert, C. R., S. L. Gardner, AND D.W. Duszynskı. 1988. Coccidia (Apicomplexa: Eimeriidae) from the Subterranean Rodent Ctenomys opimus Wagner (Ctenomyidae) from Bolivia, South America. The Journal of Parasitology 74:1018-1022.

Lendemer, J., B. Thiers, A. K. Monfils, J. Zaspel, E. R. Ellwood, A. Bentley, K. LeVan, J. Bates, D. Jennings, D. Contreras., and L. Lagomarsino. 2020. The Extended Specimen Network: A Strategy to Enhance US Biodiversity Collections, Promote Research and Education. BioScience 70:23-30.

Longo, M. S., M. J. O’Neill, ANd R. J. O’Neill. 2011. Abundant human DNA contamination identified in non-primate genome databases. PLoS One 6:e16410.

Malaney, J. L., AND J. A. Cook. 2018. A perfect storm for mammalogy: declining sample availability in a period of rapid environmental degradation. Journal of Mammalogy 99:773-788.

Mclean, B. S., K. C., Bell, J. L. Dunnum, B. Abrahamson, J. P. Colella, E. R. Deardorff, J. A. Weber, A. K. Jones, F. SalazarMiralles, ANd J. A. Cook. 2016. Natural history collectionsbased research: progress, promise, and best practices. Journal of Mammalogy 97:287-297.

Myers, P., And J. L. Patton. 1989. A new species of Akodon from the cloud forests of eastern Cochabamba Department, Bolivia (Rodentia: Sigmodontinae). Occasional Papers of the Museum of Zoology, University of Michigan 720:1-28.

Notarincola, J., F. A. Jiménez-Ruiz, and S. L. Gardner. 2007. A new species of Dipetalonema (Filarioidea: Onchocercidae) from Ateles chamek from the Beni of Bolivia. Journal of Parasitology 93:661-667.

Notarnicola, J., F. A. Jiménez, And S. L., Gardner. 2012. A new species of Molinema (Nematoda: Onchocercidae) in Bolivian rodents and emended description of Litomosoides esslingeri Bain, Petit, and Diagne, 1989. Journal of Parasitology 98:1200-1208.

Olds, N., And S. Anderson. 1987. Notes on Bolivian mammals. 2. Taxonomy and distribution of rice rats on the subgenus Oligoryzomys. Studies in Neotropical Mammalogy, Essays in honor of Philip Hershkovitz (Patterson, B. D., y R. M. Timm, eds.). Fieldiana: Zoology (n. ser) 39:261-281

Olds, N., And S. Anderson. 1989. A diagnosis of the tribe Phyllotini (Rodentia, Muridae). Pp. 55-74 Advances in Neotropical mammalogy (Redford, K. H., and J. F. Eisenberg, eds.). Sandhill Crane Press, Gainesville, U.S.A.

Olds, N., S. Anderson, And T. L. Yates. 1987. Notes on Bolivian Mammals 3. A revised diagnosis of Andalgalomys (Rodentia, Muridae) and the description of a new subspecies. Novitates 2890:1-17.

Patton, J. L., U. F Pardiñas, And G. D'Elía, (eds). 2015. Mammals of South America, volume 2: Rodents. University of Chicago Press. Chicago, U.S.A.

Pauli, J.N., S. D. Newsome, J. A. Cook, C. Harrod, S. A. Steffan, C. Baker, M. Ben-David, D. Bloom, G. Brown, T. Cerling, C. Cicero, C. Cook, M. Dohm, J. Eherlinger, S. Federhen, B. Frey, P. Ghosh, G. Graves, R. Gropp, K. Hobson, C. Jordan, T. O'Connell, S. Pilaar Birch, J. Poelen, S. Ratnasingham, L. Russell, C. Stricker, M. Uhen, C. Yarnes, and B. Hayden. 2017 . Opinion: Why we need a centralized repository for isotopic data. Proceedings National Academy Sciences, USA 114:2997-3001.

Rios, N. E., AND H. L. BART, JR. 2014. Geolocate User's Manual. http://www.museum.tulane.edu/ geolocate/standalone/ manual ver2 0.pdf Accessed on March 10, 2020.

Salazar-Bravo, J., and T. L. Yates. 2007. A new species of Thomasomys (Cricetidae: Sigmodontinae) from central Bolivia. Pp. 747-774 in The quintessential naturalist: honoring the life and legacy of Oliver P. Pearson (Kelt, D. A., E. P. Lessa, J. Salazar-Bravo, and J. L. Patton, eds.). University of California Publications in Zoology 134:1-981.

Salazar, J., AND S. Anderson. 1990. Informe sobre el estado actual del conocimiento del oso andino en Bolivia. Ecologia en Bolivia 15:3-23.

Salazar, J. A., M. L. Campbell, S. Anderson, S. L. Gardner, and J. L. Dunnum. 1994. New records of Bolivian mammals. Mammalia 58:125-130.

Salazar-Bravo, J., T. Tarifa, L. F. Aguirre, E. Yensen, and T. L. Yates. 2003. Revised checklist of Bolivian mammals. Occasional Papers, Museum of Texas Tech University 220:1-27.

Schmitt, C. J., J. A. Cook, K. Zamudio, and S. V. Edwards. 2018. Museum specimens of terrestrial vertebrates are sensitive indicators of environmental change in the Anthropocene. Philosophical Transactions Royal Society B 374:20170387.

Schindel, D. E. AND J. A. Cook. 2018. The next generation of natural history collections. PLoS Biology 16:p.e2006125.

TARIFA, T. 2014. Historia de la mastozoología en Bolivia. Pp. 69-106 in Historia de la mastozoología en Latinoamérica, las Guyanas y el Caribe (Ortega, J., J. L. Martínez, and D. G. Tirira, eds). Editorial Murciélago Blanco y Asociación Ecuatoriana de Mastozoología. Quito, Ecuador y Ciudad de México, México.

Voss, R. S., R. H. PIne, And S. Solari. 2012. A new species of the didelphid marsupial genus Monodelphis from Eastern Bolivia. American Museum Novitates 3740:1-14.

Webster, M. S. 2017. The Extended Specimen: Emerging Frontiers in Collections-based Ornithological Research. CRC Press/Taylor \& Francis Group. Boca Raton, U.S.A.

Associated editor: Jorge Salazar-Bravo

Submitted: May 7, 2020; Reviewed: June 18, 2020;

Accepted: June 20, 2020; Published on line: July 27, 2020. 